Brit. J. vener. Dis. (1963), 39, 261.

\title{
CLINICAL COMMENTS ON THE START OF AN EPIDEMIC OF SYPHILIS*
}

\author{
BY \\ SVEN ANCHER KVORNING \\ Department of Skin and Venereal Diseases, Kommunehospitalet, Copenhagen
}

Late in 1960 an epidemic of syphilis started in Copenhagen where the infection had been rare for several years. It came upon us rather unexpectedly, although the incidence of gonorrhoea was known to have doubled in the two preceding years.

The start of this epidemic seemed quite alarming, as the number of cases increased ten-fold from one quarter of the year to the next. The group of patients treated by the University Clinic appeared to be fairly representative of conditions in the city as a whole and I shall limit my account to a description of 103 consecutive patients treated at the clinic, comparing some of the facts with those relating to the patients treated in the same institution in 1949. The incidence in 1961 was exactly the same as in 1949 during the decline of the epidemic associated with the second world war.

The Figure shows the number of new infections seen at the clinic in the period studied, each column representing a quarter of a year. The sudden increase

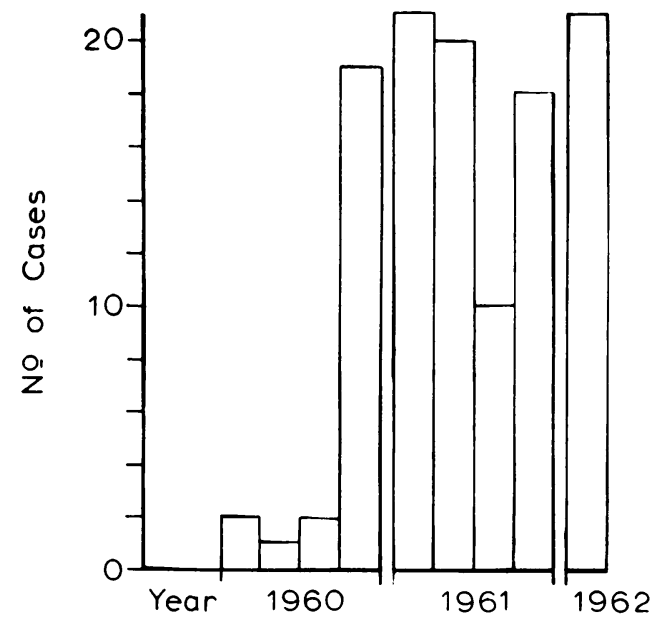

FIgURE.-Cases of syphilis seen in 1960-62 in the University Clinic. Each column indicates the number of new cases in a 3-month period.

\footnotetext{
* Paper read at M.S.S.V.D. meeting in Copenhagen, June 7, 1963.
}

and fairly uniform distribution thereafter corresponded to the total incidence reported to the authorities in the same period, and we have no reason to suspect that many infections were undiagnosed previously.

Sex.-Table I shows the sex distribution in 1949 and 1961. The majority of patients in 1949 were women, which is a little unusual, but in 1961 there was an extraordinarily high majority of men.

TABLE I

SEX, DIAGNOSIS, AND CONCURRENT DISEASE IN 1949 AND 1961

\begin{tabular}{|c|c|c|c|c|}
\hline Year $\quad$. & . & . & 1949 & 1961 \\
\hline Sex & $\begin{array}{l}\text { Male } \\
\text { Female }\end{array}$ & & $\left.\begin{array}{l}36 \\
46\end{array}\right\} 82$ & $\left.\begin{array}{l}63 \\
19\end{array}\right\} 82$ \\
\hline \multirow{2}{*}{$\begin{array}{l}\text { Diagnosis } \\
\text { (per cent.) }\end{array}$} & Primary & $\begin{array}{l}\text { Sero-negative } \\
\text { Sero-positive }\end{array}$ & $\begin{array}{l}15 \\
24\end{array}$ & $\begin{array}{l}19 \\
26\end{array}$ \\
\hline & \multicolumn{2}{|l|}{ Secondary } & 61 & 55 \\
\hline \multirow{5}{*}{$\begin{array}{l}\text { Other } \\
\text { Disease }\end{array}$} & Gonorrhoea & $\begin{array}{l}\text { Male } \\
\text { Female }\end{array}$ & $\begin{array}{l}0 \\
6\end{array}$ & $\begin{array}{r}10 \\
0\end{array}$ \\
\hline & Chancroid & $\begin{array}{l}\text { Male } \\
\text { Female }\end{array}$ & $\begin{array}{l}0 \\
0\end{array}$ & $\begin{array}{l}3 \\
0\end{array}$ \\
\hline & Condylomata & $\begin{array}{l}\text { Male } \\
\text { Female }\end{array}$ & $\begin{array}{l}1 \\
0\end{array}$ & $\begin{array}{l}5 \\
1\end{array}$ \\
\hline & Pediculosis & $\begin{array}{l}\text { Male } \\
\text { Female }\end{array}$ & $\begin{array}{l}2 \\
5\end{array}$ & $\begin{array}{l}2 \\
0\end{array}$ \\
\hline & Scabies & $\begin{array}{l}\text { Male } \\
\text { Female }\end{array}$ & $\begin{array}{l}1 \\
2\end{array}$ & 1 \\
\hline
\end{tabular}

Stage of Syphilis.-The stage of infection at the time of diagnosis was classified into sero-negative and sero-positive primary and secondary lesions (Table I). The percentage distribution of the patients according to these criteria is broadly similar to that in 1949. Some patients complained of impaired general health with fever, headache, loss of appetite etc.; this feature was recorded for thirteen patients in 1961 but only for four in 1949. There is nothing to suggest that either the patients or the physicians had become more symptom-conscious in the intervening period. 
Concurrent Disease.-The incidence of concurrent venereal or para-venereal disease (Table 1 ) is surprising. These associated conditions were more frequent in women in 1949 and more frequent in men in 1961. The three cases of chancroid seen in 1961 represent a rarity in Denmark, indicating that this infection had most likely been contracted abroad.

Treatment.-In 1949 nearly all patients were given bismuth and Mapharsen initially, and very few were treated with penicillin. In 1961 all patients received penicillin, except one who had an intolerance to this drug and was given oral oxytetracycline.

Side-Effects.-In 1949, 15 per cent. of the patients had an initial reaction to treatment of the JarischHerxheimer type and 35 per cent. developed late symptoms of drug intoxication. In 1961, 78 per cent. had a Jarisch-Herxheimer reaction but none had late symptoms of intolerance.

Sexual Behaviour.-The most surprising feature was the unusual distribution between the sexes, which led us to investigate the patients' sexual relationships. Many of the men had had homosexual experience and for this reason the males were questioned more carefully to evaluate the spread of infection under these conditions.

\section{Male Patients.}

Age.-The changed age distribution (Table II) with many more older patients in 1961 may have been caused as much by changing social customs as by changing sex habits in the older generations.

TABLE II

AGE DISTRIBUTION, MARITAL STATUS, AND SEXUAL BEHAVIOUR OF MALE PATIENTS

\begin{tabular}{|c|c|c|c|c|}
\hline Year .. & . & .. & 1949 & 1961 \\
\hline $\begin{array}{c}\text { Age } \\
\text { (yrs) }\end{array}$ & $\begin{array}{l}\text { Under } 15 \\
16-20 \\
21-25 \\
26-30 \\
31-35 \\
36-40 \\
41-50 \\
\text { Over } 51\end{array}$ & & $\begin{array}{r}1 \\
5 \\
12 \\
4 \\
12 \\
1 \\
1 \\
0\end{array}$ & $\begin{array}{r}0 \\
9 \\
21 \\
14 \\
13 \\
7 \\
10 \\
7\end{array}$ \\
\hline $\begin{array}{l}\text { Marital } \\
\text { Status }\end{array}$ & $\begin{array}{l}\text { Unmarried } \\
\text { Married } \\
\text { Divorced } \\
\text { Widower }\end{array}$ & & $\begin{array}{r}25 \\
7 \\
4 \\
-\end{array}$ & $\begin{array}{r}52 \\
18 \\
9 \\
2\end{array}$ \\
\hline \multirow{3}{*}{$\begin{array}{l}\text { Contact } \\
\text { Tracing }\end{array}$} & Heterosexual & $\begin{array}{l}\text { Partner known } \\
\text { Partner not known }\end{array}$ & $\begin{array}{r}32 \\
2\end{array}$ & $\begin{array}{l}30 \\
12\end{array}$ \\
\hline & \multicolumn{2}{|l|}{ Homosexual } & 1 & 20 \\
\hline & \multicolumn{2}{|l|}{ Ambivalent } & 1 & 19 \\
\hline
\end{tabular}

Marital Status.-The slight changes in marital status (Table II) correspond to the changed age distribution.

Contact-Tracing.-Comparing the contact-tracing records in 1949 and 1961 (Table II), the record of 1949 seems more successful. The heterosexuals are divided into those who were able to trace one or more of their female contacts, and those who, while claiming a history of intercourse, could not identify the sexual partner. If a homosexual wanted to represent himself as heterosexual, he could invent a story of a female contact or contacts, but these could never be traced.

Sexual Deviation.-In 1949 all the heterosexual contacts were verified, except in two cases both sailors. In 1961 over a quarter of the patients could not provide reasonable evidence to support their claim to heterosexual exposure, and if we adopt a very suspicious attitude we may suppose that some men in the heterosexual group did not admit to homosexuality.

There was however a much larger percentage in 1961 who admitted homosexuality, and this perhaps reflects a more open attitude on the subject between doctor and patient. Our sample clearly demonstrates that some males alternate between female and male partners.

Promiscuity.-Table III classifies the promiscuity of the patients, heterosexual as well as homosexual, according to frequency of contacts ("infrequent" means less than once a month. "occasional" more than once a month but less than once a week, "promiscuous" more than three partners within the last 2 months). Table III shows that sexual ambivalence is very common but is more often associated with a lower rate of activity.

TABLE III

PARTNERS OF MALE PATIENTS

\begin{tabular}{l|l|c|c|c}
\hline \multicolumn{2}{l|}{} & \multicolumn{2}{|c|}{ Heterosexual } & Homosexual \\
\cline { 1 - 3 } Year & & 1949 & 1961 & 1961 \\
\hline \multirow{2}{*}{ Partner } & Infrequent contact & 1 & $6(1)$ & $2(2)$ \\
& Occasional contact & 8 & $28(9)$ & $20(15)$ \\
& Constant & 4 & $7(5)$ & $2(0)$ \\
& Promiscuous & 22 & $20(4)$ & $15(2)$ \\
\hline Total & & 35 & $61(19)$ & $39(19)$ \\
\hline
\end{tabular}

Nos. in brackets indicate ambivalents included in numbers for 1961. 
Site of Infection.- The site of the primary lesion is analysed according to the sexual behaviour of the individual, in Table IV. It is obvious that a tonsillar infection is mechanically much better explained by homosexual association.

\section{TABLE IV}

SITE OF PRIMARY LESIONS IN 75 MALES IN 1961

\begin{tabular}{l|c|c|c|c|c}
\hline \multicolumn{1}{|l|}{ Sexual Behaviour } & $\begin{array}{c}\text { Hetero- } \\
\text { sexual }\end{array}$ & $\begin{array}{c}\text { Ambi- } \\
\text { valent }\end{array}$ & $\begin{array}{c}\text { Homo- } \\
\text { sexual }\end{array}$ & Total \\
\hline & Genitals & 29 & 6 & 10 & 45 \\
\cline { 2 - 6 } $\begin{array}{l}\text { Site of } \\
\text { Chancre }\end{array}$ & Anus & 3 & 5 & 5 & 13 \\
\cline { 2 - 6 } & Tonsil & 0 & 0 & 2 & 2 \\
\cline { 2 - 6 } & Arm & 0 & 1 & 0 & 1 \\
\hline Total & No Chancre & 4 & 8 & 2 & 14 \\
\hline
\end{tabular}

Male:Female Ratio.-The changes in the male: female ratio seen in our patients towards the end of one epidemic (1949) and the beginning of another (1961) correspond to the ratio in Denmark as a whole. This may be explained by assuming the constant existence of an infected group with rather varying sexual activity but with little interest in medical advice and only a limited contact with more sedate citizens; this reservoir of infection only touches the "respectable" when the solid citizens are looking for extra excitement or are "displaced" either as military personnel or as tourists.

\section{Summary}

In 1961 a new epidemic of syphilis suddenly started in Copenhagen with a sex ratio of three males to one female, whereas in 1949, during the decline of the world war II epidemic the ratio had been $4: 5$. This can be partly accounted for by the large number of homosexual and ambivalent male patients. The clinical picture at diagnosis has not changed.

Penicillin therapy carries a high incidence of Jarisch-Herxheimer reactions but has caused no serious complications in this group of patients.

\section{Une épidémie soudaine de syphilis}

\section{RÉSUMÉ}

Une nouvelle épidemie de syphilis éclata subitement à Copenhague en 1961. Le rapport hommes/femmes fut 3:1, tandis qu'en 1949, vers la fin de l'épidémie de la seconde guerre mondiale, le rapport fut 4:5.

Ce phénomène peut s'éxpliquer par le grand nombre d'homosexuels et de mâles dont la vie sexuelle est équivoque.

Le diagnostic s'appuie encore sur les indications cliniques traditionelles. L'emploi de la pénicilline est accompagné d'habitude d'un assez grand nombre de réactions Jarisch-Herxheimer, mais les complications graves chez ce groupe de malades sont rares. 